OPEN ACCESS

Edited by:

Hernandes F. Carvalho, State University of Campinas, Brazil

Reviewed by:

Sabrina Battista,

Consiglio Nazionale Delle Ricerche

(CNR), Italy

Bashdar Mahmud Hussen,

Hawler Medical University, Iraq

*Correspondence:

Shiwei Duan

duansw@zucc.edu.cn

${ }^{\dagger}$ These authors share first authorship

Specialty section:

This article was submitted to Molecular and Cellular Oncology, a section of the journal Frontiers in Cell and Developmental Biology

Received: 04 November 2021 Accepted: 20 January 2022

Published: 18 February 2022

Citation: Xie Z, Zhong C and Duan S (2022) miR1269a and miR-1269b: Emerging Carcinogenic Genes of the miR1269 Family.

Front. Cell Dev. Biol. 10:809132. doi: 10.3389/fcell.2022.809132

\section{miR-1269a and miR-1269b: Emerging Carcinogenic Genes of the miR-1269 Family}

\author{
Zijun Xie ${ }^{1,2 \dagger}$, Chenming Zhong ${ }^{1,2 \dagger}$ and Shiwei Duan ${ }^{1,3 *}$ \\ ${ }^{1}$ School of Medicine, Zhejiang University City College, Hangzhou, China, ${ }^{2}$ Medical Genetics Center, School of Medicine, Ningbo \\ University, Ningbo, China, ${ }^{3}$ Department of Clinical Medicine, Zhejiang University City College School of Medicine, Hangzhou, \\ China
}

miRNAs play an important role in the occurrence and development of human cancer. Among them, hsa-mir-1269a and hsa-mir-1269b are located on human chromosomes 4 and 17, respectively, and their mature miRNAs (miR-1269a and miR-1269b) have the same sequence. miR-1269a is overexpressed in 9 cancers. The high expression of miR1269a not only has diagnostic significance in hepatocellular carcinoma and non-small cell lung cancer but also is related to the poor prognosis of cancer patients such as esophageal cancer, hepatocellular carcinoma, and glioma. miR-1269a can target 8 downstream genes (CXCL9, SOX6, FOXO1, ATRX, RASSF9, SMAD7, HOXD10, and VASH1). The expression of miR-1269a is regulated by three non-coding RNAs (RP11-1094M14.8, LINC00261, and circASS1). miR-1269a participates in the regulation of the TGF- $\beta$ signaling pathway, PI3K/AKT signaling pathway, p53 signaling pathway, and caspase-9-mediated apoptotic pathway, thereby affecting the occurrence and development of cancer. There are fewer studies on miR-1269b compared to miR-1269a. miR-1269b is highly expressed in hepatocellular carcinoma, non-small cell lung cancer, oral squamous cell carcinoma, and pharyngeal squamous cell carcinoma, but miR-1269b is low expressed in gastric cancer. miR-1269b can target downstream genes (METTL3, CDC40, SVEP1, and PTEN) and regulate the PI3K/AKT signaling pathway. In addition, sequence mutations on miR1269a and miR-1269b can affect their regulation of cancer. The current studies have shown that miR-1269a and miR-1269b have the potential to be diagnostic and prognostic markers for cancer. Future research on miR-1269a and miR-1269b can focus on elucidating more of their upstream and downstream genes and exploring the clinical application value of miR-1269a and miR-1269b.At present, there is no systematic summary of the research on miR-1269a and miR-1269b. This paper aims to comprehensively analyze the abnormal expression, diagnostic and prognostic value, and molecular regulatory pathways of miR-1269a and miR-1269b in multiple cancers. The overview in our work can provide useful clues and directions for future related research.

Keywords: miR-1269a, miR-1269b, target gene, non-coding RNAs, prognosis 


\section{INTRODUCTION}

MicroRNA (miRNA) is an endogenous non-coding RNA with a length of 20-22 nucleotides, which can usually bind to the $3^{\prime}$ untranslated region of its target gene to silence gene expression (Ambros, 2004). hsa-mir-1269a at chromosome 4 and hsa-mir$1269 \mathrm{~b}$ at chromosome 17 are members of the miR-1269 family. They can produce mature miRNAs (miR-1269a and miR-1269b) (Kong et al., 2016) with the same sequence.

At present, there are many bioinformatics studies on miRNA. Tens of miRNA research tools are integrated on the tools4mirs website (https://tools4mirs.org/) (Lukasik et al., 2016). miRNA target gene prediction tools mainly used in the miR-1269 related studies include TargetScan (http://www.targetscan.org/) (McGeary et al., 2019), miRDB (http://www.mirdb.org/ miRDB/) (Chen and Wang, 2020), and mirwalk (http:/// mirwalk.umm.uni-heidelberg.de/) (Sticht et al., 2018).

miR-1269a is abnormally highly expressed in 9 cancers, used for the diagnosis of 6 cancers, and is also related to the prognosis of 6 cancers. miR-1269a is also involved in the occurrence and progression of diseases other than cancer. For example, the high expression of miR-1269a may be a risk factor for ectopic pregnancy (Zhang et al., 2018). miR-1269a can regulate the expression of 8 downstream genes and is related to the regulation of three signaling pathways. As to miR-1269b, it is abnormally expressed in 4 kinds of cancers (3 kinds of high expression, one kind of low expression), and is related to the prognosis of two kinds of cancers. miR-1269b can regulate 4 downstream genes and participate in two signaling pathways. In addition, the genetic variants of both miR-1269a and miR-1269b can affect the function of their wild types.

Although there are many reports on miR-1269a and miR$1269 \mathrm{~b}$, there is no systematic summary of the two miRNAs. Because miR-1269a and miR-1269b have the same sequence and similar names, researchers may confuse these two miRNAs. Therefore, this article summarizes the abnormal expression of miR-1269a and miR-1269b in various cancers and their diagnostic and prognostic value in cancer. In addition, this article comprehensively analyzes the molecular regulation pathways related to miR-1269a and miR-1269b, which is expected to provide guidance for future related research.

\section{ONCOLOGICAL ROLE OF MIR-1269A AND MIR-1269B IN CANCER}

miR-1269a is highly expressed in 9 cancers, including hepatocellular carcinoma (Wojcicka et al., 2014; Yang et al., 2014; Gan et al., 2015; Elemeery et al., 2017; Wang et al., 2019; Cho et al., 2020), lung cancer (Bao et al., 2018; Jin et al., 2018; Guo et al., 2020; Wang et al., 2020; Du et al., 2021; Le and Le, 2021), gastric cancer (Liu et al., 2019; Zhang K. et al., 2020), colon cancer (Bu et al., 2015; Xiong et al., 2021), esophageal cancer (Bai et al., 2021; Yu and Ren, 2021; Zhao et al., 2021), clear cell renal cell carcinoma (Qin et al., 2019; Zhan et al., 2021), head and neck squamous cell carcinoma (Nunez Lopez et al., 2018), glioma (Zhang Y. et al., 2020), and acute myeloid leukemia (Li and Ge, 2021). Highly expressed miR-1269a can promote cancer cell proliferation, migration, invasion, epithelial-mesenchymal transition, and inhibit cancer cell apoptosis (Table 1). It is worth noting that in hepatocellular carcinoma (Xiong et al., 2015; Min et al., 2017) and gastric cancer (Li et al., 2017), there are highly expressed miR-1269a mutant and low expressed miR-1269a wild type. Interestingly, the miR-1269a mutant can inhibit the cancerpromoting effect of wild-type miR-1269a, which provides very valuable evidence for targeted cancer therapy.

Similarly, miR-1269b is also highly expressed in hepatocellular carcinoma (Kong et al., 2016; Chen et al., 2020; Ma et al., 2020), lung cancer (Yang et al., 2020), and oral and pharyngeal squamous cell carcinoma (Chen et al., 2016). Overexpression of miR-1269b can down-regulate METTL3, thereby inhibiting the proliferation, migration, and invasion of gastric cancer cells (Kang et al., 2021). It is worth noting that miR-1269b is low expressed in gastric cancer (Table 1).

Changes in miRNA expression are a fundamental component of cancer progression. The current study shows that the aberrant expression of miR-1269a or miR-1269b is present in a variety of cancers. Overall, abnormal expression of miR-1269a and miR-1269b can promote or interfere with the occurrence and development of cancer by regulating biological processes such as cancer cell proliferation, migration, invasion, apoptosis, and epithelial-mesenchymal transition. The abnormal expression of miR-1269a and miR$1269 \mathrm{~b}$ may reflect the regulation of ceRNAs or other upstream genes in different tumors. We also observed that different detection methods of miR-1269a/b were used in these studies. As shown in Supplementary Table S1, qRT-PCR is commonly used to detect the expression of miR-1269a (Yang et al., 2014; Bu et al., 2015; Gan et al., 2015; Scaravilli et al., 2015; Kong et al., 2016; Li et al., 2017; Min et al., 2017; Jin et al., 2018; Liu et al., 2019; Zhang K. et al., 2020; Zhang Y. et al., 2020; Chen et al., 2020; Cho et al., 2020; Guo et al., 2020; Bai et al., 2021; Kang et al., 2021; Li and Ge, 2021; Xiong et al., 2021). Some studies have also applied RTPCR technology to detect miR-1269 expression for hepatocellular carcinoma (Xiong et al., 2015; Elemeery et al., 2017), lung cancer (Elemeery et al., 2017; Wang et al., 2020), and oropharyngeal squamous cell carcinoma (Chen et al., 2016). In addition, studies in hepatocellular carcinoma and acute myeloid leukemia used nextgeneration sequencing technology (Wojcicka et al., 2014; Chen et al., 2020; Cho et al., 2020) and transcriptome high-throughput sequencing ( $\mathrm{Li}$ and Ge, 2021) to detect miR-1269. Most of the studies provided the primer sequences used in the experiments, but some studies directly used the data in the database without providing the corresponding primer sequences (Wojcicka et al., 2014; Yang et al., 2014; Bu et al., 2015; Scaravilli et al., 2015; Xiong et al., 2015; Chen et al., 2016; Elemeery et al., 2017; Min et al., 2017; Bao et al., 2018; Yang et al., 2020; Bai et al., 2021; Le and Le, 2021; Li and Ge, 2021). Furthermore, we notice that there is a microarray platform (Illumina HumanHT-12 V4.0 expression beadchip) that can detect miR-1269a, but not 
TABLE 1 | The role of miR-1269a and miR-1269b in different human cancers.

\begin{tabular}{|c|c|c|c|c|c|c|c|c|}
\hline $\begin{array}{l}\mathrm{miR}- \\
1269 \mathrm{a} / \mathrm{b}\end{array}$ & $\begin{array}{l}\text { Tumor } \\
\text { type }\end{array}$ & $\begin{array}{l}\text { Expression } \\
\text { pattern }\end{array}$ & $\begin{array}{l}\text { Number } \\
\text { of clinical } \\
\text { samples }\end{array}$ & $\begin{array}{l}\text { Assessed } \\
\text { cell } \\
\text { lines }\end{array}$ & $\begin{array}{l}\text { Effect } \\
\text { in vitro }\end{array}$ & $\begin{array}{l}\text { Effect } \\
\text { in vivo }\end{array}$ & $\begin{array}{l}\text { Regulatory } \\
\text { mechanism }\end{array}$ & Ref \\
\hline \multicolumn{9}{|c|}{ miR-1269a } \\
\hline & $\mathrm{HCC}$ & Up-regulated & $\begin{array}{l}723 \text { cases and } \\
698 \text { controls }\end{array}$ & HepG2 and SMMC-7721 & $\begin{array}{l}\text { Proliferation } \uparrow \text {, } \\
\text { Apoptosis } \downarrow\end{array}$ & - & $\begin{array}{l}\text { miR-1269a/ } \\
\text { SPATS2L and } \\
\text { LRP6 axis }\end{array}$ & $\begin{array}{l}\text { Min et al. } \\
(2017)\end{array}$ \\
\hline & $\mathrm{HCC}$ & Up-regulated & $\begin{array}{l}590 \text { cases and } \\
549 \text { controls }\end{array}$ & HepG2 and Huh7 & Proliferation $\uparrow$ & - & $\begin{array}{l}\text { miR-1269a/ } \\
\text { sox6 axis }\end{array}$ & $\begin{array}{l}\text { Xiong et al. } \\
(2015)\end{array}$ \\
\hline & $\mathrm{HCC}$ & Up-regulated & 23 paired tissues & $\begin{array}{l}\text { HepG2, Huh7, Hep3B, } \\
\text { THLE3, BEL-7402, BEL- } \\
\text { 7404, SNU-398, SNU- } \\
\text { 449, and QGY-7703 }\end{array}$ & $\begin{array}{l}\text { Proliferation } \uparrow, \\
\text { Tumorigenicity } \uparrow, \text { Cell } \\
\text { cycle } \uparrow\end{array}$ & - & $\begin{array}{l}\text { miR-1269a/ } \\
\text { FOX01 axis }\end{array}$ & $\begin{array}{l}\text { Yang et al. } \\
(2014)\end{array}$ \\
\hline & $\mathrm{HCC}$ & Up-regulated & 24 paired tissues & - & - & - & - & $\begin{array}{l}\text { Wojcicka } \\
\text { et al. (2014) }\end{array}$ \\
\hline & $\mathrm{HCC}$ & Up-regulated & $\begin{array}{l}375 \text { cases and } \\
50 \text { controls }\end{array}$ & - & - & - & - & $\begin{array}{l}\text { Wang et al. } \\
\text { (2019) }\end{array}$ \\
\hline & $\mathrm{HCC}$ & Up-regulated & $\begin{array}{l}108 \text { tissues and } \\
720 \text { serums }\end{array}$ & - & - & - & - & $\begin{array}{l}\text { Cho et al. } \\
(2020)\end{array}$ \\
\hline & $\mathrm{HCC}$ & Up-regulated & 95 paired tissues & - & - & - & - & $\begin{array}{l}\text { Gan et al. } \\
(2015)\end{array}$ \\
\hline & $\mathrm{HCC}$ & Up-regulated & $\begin{array}{l}474 \text { cases and } \\
84 \text { controls }\end{array}$ & - & - & - & - & $\begin{array}{l}\text { Elemeery } \\
\text { et al. (2017) }\end{array}$ \\
\hline & GC & Up-regulated & $\begin{array}{l}373 \text { paired } \\
\text { tissues and } 402 \\
\text { controls }\end{array}$ & MGC803 and HGC27 & $\begin{array}{l}\text { Proliferation } \uparrow, \\
\text { Apoptosis } \downarrow\end{array}$ & - & $\begin{array}{l}\text { miR-1269a/ } \\
\text { ZNF70 axis }\end{array}$ & $\begin{array}{l}\text { Li et al. } \\
(2017)\end{array}$ \\
\hline & GC & Up-regulated & - & $\begin{array}{l}\text { AGS, MKN45, NCl-N87, } \\
\text { MGC803, and GES-1 }\end{array}$ & - & $\begin{array}{l}\text { Tumor } \\
\text { growth } \uparrow\end{array}$ & $\begin{array}{l}\text { RP11- } \\
\text { 1094M14.8/miR- } \\
\text { 1269a/CXCL9 } \\
\text { axis }\end{array}$ & $\begin{array}{l}\text { Zhang K. } \\
\text { et al. (2020) }\end{array}$ \\
\hline & GC & Up-regulated & 73 paired tissues & $\begin{array}{l}\text { AGS, MKN45, BGC-823, } \\
\text { SGC7901, and GES-1 }\end{array}$ & $\begin{array}{l}\text { Proliferation } \uparrow, \text { Cell } \\
\text { cycle } \uparrow, \text { Apoptosis } \downarrow\end{array}$ & - & $\begin{array}{l}\text { miR-1269a/ } \\
\text { RASSF9 axis }\end{array}$ & $\begin{array}{l}\text { Liu et al. } \\
\text { (2019) }\end{array}$ \\
\hline & NSCLC & Up-regulated & $\begin{array}{l}147 \text { peripheral } \\
\text { blood samples } \\
\text { and } 149 \text { controls }\end{array}$ & A549 and H1975 & $\begin{array}{l}\text { Proliferation } \uparrow, \text { Migration } \\
\text { and Invasion } \uparrow, \text { EMT } \uparrow\end{array}$ & - & $\begin{array}{l}\text { miR-1269a/ } \\
\text { FOXO1 axis }\end{array}$ & $\begin{array}{l}\text { Wang et al. } \\
(2020)\end{array}$ \\
\hline & NSCLC & Up-regulated & 49 paired tissues & $\begin{array}{l}\text { A549, SPC-A1, PC-9, } \\
\text { H1299, H1975, H460, } \\
\text { and BEAS-2B }\end{array}$ & $\begin{array}{l}\text { Proliferation } \uparrow, \text { Colony } \\
\text { formation } \uparrow, \text { Cell cycle } \uparrow\end{array}$ & - & $\begin{array}{l}\text { miR-1269a/ } \\
\text { sOX6 axis }\end{array}$ & $\begin{array}{l}\text { Jin et al. } \\
(2018)\end{array}$ \\
\hline & NSCLC & Up-regulated & $\begin{array}{l}134 \text { cases and } \\
50 \text { controls }\end{array}$ & - & - & - & - & $\begin{array}{l}\text { Le and Le, } \\
\text { (2021) }\end{array}$ \\
\hline & LC & Up-regulated & 78 paired tissues & $\begin{array}{l}\text { A549, SPC-A1, } \\
\text { CBP60577, NCl-H1299, } \\
\text { NCl-H23, L78, and } \\
\text { BEAS-2B }\end{array}$ & $\begin{array}{l}\text { Proliferation } \uparrow \text {, Migration } \\
\text { and Invasion } \uparrow \text {, Cell } \\
\text { cycle } \uparrow, \text { Apoptosis } \downarrow\end{array}$ & $\begin{array}{l}\text { Tumor } \\
\text { growth } \uparrow\end{array}$ & $\begin{array}{l}\text { LINC00261/miR- } \\
\text { 1269a/FOXO1 } \\
\text { axis }\end{array}$ & $\begin{array}{l}\text { Guo et al. } \\
(2020)\end{array}$ \\
\hline & LC & Up-regulated & 52 paired tissues & A549 & $\begin{array}{l}\text { Proliferation } \uparrow, \\
\text { Apoptosis } \downarrow\end{array}$ & - & $\begin{array}{l}\text { miR-1269a/TP53 } \\
\text { and CASP9 axis }\end{array}$ & $\begin{array}{l}\text { Bao et al. } \\
\text { (2018) }\end{array}$ \\
\hline & $\mathrm{CRC}$ & Up-regulated & 100 cases & $\begin{array}{l}\text { HCT116, LoVo, HT29, } \\
\text { SW480, SW620, DLD1, } \\
\text { and LS174T }\end{array}$ & $\begin{array}{l}\text { Migration and } \\
\text { Invasion } \uparrow, \text { EMT } \uparrow\end{array}$ & $\begin{array}{l}\text { Tumor growth } \\
\text { and } \\
\text { metastasis } \uparrow\end{array}$ & $\begin{array}{l}\text { TGF- } \beta \text { positive } \\
\text { feedback } \\
\text { pathway }\end{array}$ & $\begin{array}{l}\text { Bu et al. } \\
\text { (2015) }\end{array}$ \\
\hline & CRC & Up-regulated & 10 paired tissues & $\begin{array}{l}\text { HCT116, LoVo, HT29, } \\
\text { SW480, Caco2, and } \\
\text { HIEC } 6\end{array}$ & $\begin{array}{l}\text { Proliferation } \uparrow \text {, Migration } \\
\text { and Invasion } \uparrow \text {, } \\
\text { Apoptosis } \downarrow\end{array}$ & - & $\begin{array}{l}\text { circASS1/miR- } \\
\text { 1269a/NASH1 } \\
\text { axis }\end{array}$ & $\begin{array}{l}\text { Xiong et al. } \\
(2021)\end{array}$ \\
\hline & ESCC & Up-regulated & $\begin{array}{l}107 \text { paired } \\
\text { tissues }\end{array}$ & $\begin{array}{l}\text { Eca-109, TE-1, KYSE- } \\
\text { 150, TE-10, and Het-1A }\end{array}$ & $\begin{array}{l}\text { Proliferation } \uparrow \text {, Migration } \\
\text { and Invasion } \uparrow\end{array}$ & - & $\begin{array}{l}\text { miR-1269a/ } \\
\text { SOX6 axis }\end{array}$ & $\begin{array}{l}\text { Bai et al. } \\
(2021)\end{array}$ \\
\hline & ccRCC & Up-regulated & $\begin{array}{l}480 \text { cases and } \\
68 \text { controls }\end{array}$ & - & - & - & - & $\begin{array}{l}\text { Qin et al. } \\
(2019)\end{array}$ \\
\hline & Glioma & Up-regulated & $\begin{array}{l}107 \text { paired } \\
\text { tissues; } 84 \\
\text { cases and } 10 \\
\text { controls }\end{array}$ & $\begin{array}{l}\text { U251, SNB19, SHG44, } \\
\text { A172, and HEB }\end{array}$ & $\begin{array}{l}\text { Progression } \uparrow \text {, Migration } \\
\text { and Invasion } \uparrow \text {, } \\
\text { Apoptosis } \downarrow\end{array}$ & $\begin{array}{l}\text { Tumor } \\
\text { growth } \uparrow\end{array}$ & $\begin{array}{l}\text { miR-1269a/ATRX } \\
\text { axis }\end{array}$ & $\begin{array}{l}\text { Zhang Y. } \\
\text { et al. (2020) }\end{array}$ \\
\hline & PC & Up-regulated & 135 cases & $\begin{array}{l}\text { PC3, DU145, LNCaP, } \\
\text { 22Rv1, VCaP, and HT- } \\
1080\end{array}$ & - & - & - & $\begin{array}{l}\text { Scaravilli } \\
\text { et al. (2015) }\end{array}$ \\
\hline & $\mathrm{AML}$ & Up-regulated & & - & - & - & $\begin{array}{l}- \\
\text { (Continued on follc }\end{array}$ & wing page) \\
\hline
\end{tabular}


TABLE 1 | (Continued) The role of miR-1269a and miR-1269b in different human cancers.

\begin{tabular}{|c|c|c|c|c|c|c|c|c|}
\hline $\begin{array}{l}\text { miR- } \\
1269 a / b\end{array}$ & $\begin{array}{l}\text { Tumor } \\
\text { type }\end{array}$ & $\begin{array}{l}\text { Expression } \\
\text { pattern }\end{array}$ & $\begin{array}{l}\text { Number } \\
\text { of clinical } \\
\text { samples }\end{array}$ & $\begin{array}{c}\text { Assessed } \\
\text { cell } \\
\text { lines }\end{array}$ & $\begin{array}{l}\text { Effect } \\
\text { in vitro }\end{array}$ & $\begin{array}{l}\text { Effect } \\
\text { in vivo }\end{array}$ & $\begin{array}{l}\text { Regulatory } \\
\text { mechanism }\end{array}$ & Ref \\
\hline & & & $\begin{array}{l}47 \text { cases and } 32 \\
\text { controls }\end{array}$ & & & & & $\begin{array}{l}\mathrm{Li} \text { and Ge, } \\
\text { (2021) }\end{array}$ \\
\hline \multicolumn{9}{|c|}{ miR-1269b } \\
\hline & $\mathrm{HCC}$ & Up-regulated & - & $\begin{array}{l}\text { HepG2, SMMC-7721, } \\
\text { and HepG2.2.15 }\end{array}$ & $\begin{array}{l}\text { Proliferation } \uparrow, \\
\text { Migration } \uparrow, \text { Cell cycle } \uparrow\end{array}$ & - & $\begin{array}{l}\mathrm{HBx} / \mathrm{NF}-\mathrm{kB} / \mathrm{miR}- \\
1269 \mathrm{~b} / \mathrm{CDC} 40 \\
\text { axis }\end{array}$ & $\begin{array}{l}\text { Kong et al. } \\
\text { (2016) }\end{array}$ \\
\hline & $\mathrm{HCC}$ & Up-regulated & 220 cases & $\begin{array}{l}\text { Huh7, Hep3B, PLC, HLE, } \\
\text { MHCCLM3, MHCC97H, } \\
\text { and MHCC97L }\end{array}$ & $\begin{array}{l}\text { Proliferation } \uparrow, \text { Migration } \\
\text { and Invasion } \uparrow \text {, } \\
\text { Chemotaxis } \uparrow\end{array}$ & $\begin{array}{l}\text { Tumor growth } \\
\text { and } \\
\text { metastasis } \uparrow\end{array}$ & $\begin{array}{l}\text { miR-1269b/ } \\
\text { SVEP1; PI3K/ } \\
\text { AKT pathways }\end{array}$ & $\begin{array}{l}\text { Chen et al. } \\
(2020)\end{array}$ \\
\hline & $\mathrm{HCC}$ & Up-regulated & $\begin{array}{l}415 \text { cases and } \\
334 \text { controls }\end{array}$ & - & - & - & - & $\begin{array}{l}\text { Ma et al. } \\
(2020)\end{array}$ \\
\hline & $\mathrm{GC}$ & $\begin{array}{l}\text { Down- } \\
\text { regulated }\end{array}$ & $\begin{array}{l}143 \text { paired } \\
\text { tissues }\end{array}$ & $\begin{array}{l}\text { AGS, NCl-N87, HGC27, } \\
\text { SNU-16, and GES-1 }\end{array}$ & $\begin{array}{l}\text { Proliferation } \downarrow \text {, Migration } \\
\text { and Invasion } \downarrow\end{array}$ & - & $\begin{array}{l}\text { miR-1269b/ } \\
\text { METTL3 axis }\end{array}$ & $\begin{array}{l}\text { Kang et al. } \\
(2021)\end{array}$ \\
\hline & NSCLC & Up-regulated & 32 paired tissues & $\begin{array}{l}\text { A549, A549/DDP, SPC- } \\
\text { A1, PC-9, H1299, H358, } \\
\text { and 16HBE }\end{array}$ & $\begin{array}{l}\text { Proliferation } \uparrow \text {, } \\
\text { Apoptosis } \downarrow \text {, Drug } \\
\text { resistance } \uparrow\end{array}$ & $\begin{array}{l}\text { Tumor } \\
\text { growth } \uparrow\end{array}$ & $\begin{array}{l}\text { miR-1269b/ } \\
\text { PTEN; PI3K/AKT } \\
\text { pathways }\end{array}$ & $\begin{array}{l}\text { Yang et al. } \\
(2020)\end{array}$ \\
\hline & OPSCC & Up-regulated & $\begin{array}{l}1087 \text { cases and } \\
865 \text { controls }\end{array}$ & - & - & - & - & $\begin{array}{l}\text { Chen et al. } \\
\text { (2016) }\end{array}$ \\
\hline
\end{tabular}

HCC, hepatocellular carcinoma; GC, gastric cancer; NSCLC, Non-small cell lung cancer; LC, lung cancer; CRC, colorectal cancer; ESCC, esophageal squamous cell carcinoma; ccRCC, clear cell renal cell carcinoma; PC, prostate cancer; AML, acute myeloid leukemia; OPSCC, oropharyngeal squamous cell carcinoma; $\uparrow$, Promotion; $\downarrow$, Inhibition.

TABLE 2 | The prognostic value of miR-1269a and miR-1269b in cancers.

\begin{tabular}{|c|c|c|c|c|c|}
\hline $\begin{array}{l}\text { miR- } \\
\text { 1269a/b }\end{array}$ & $\begin{array}{l}\text { Tumor } \\
\text { type }\end{array}$ & $\begin{array}{l}\text { Sample } \\
\text { size }\end{array}$ & $\begin{array}{l}\text { Expression } \\
\text { pattern }\end{array}$ & $\begin{array}{l}\text { Prognostic/Diagnostic } \\
\text { value }\end{array}$ & Ref \\
\hline \multicolumn{6}{|c|}{ miR-1269a } \\
\hline & HCC & $\begin{array}{l}254 \\
\text { patients }\end{array}$ & Up-regulated & Prognostic factor of OS and DFS & Cho et al. (2020) \\
\hline & $\mathrm{HCC}$ & 95 patients & Up-regulated & $\begin{array}{l}\text { Positively associated with vaso-invasion, multiple tumor nodes and TNM stage; AUC } \\
=0.640\end{array}$ & Gan et al. (2015) \\
\hline & $\mathrm{HCC}$ & $\begin{array}{l}224 \\
\text { patients }\end{array}$ & Up-regulated & $\begin{array}{l}\text { Positively associated with late fibrosis; } A \cup C=0.691, \text { sensitivity }=0.786, \text { specificity }= \\
0.598\end{array}$ & $\begin{array}{l}\text { Elemeery et al. } \\
(2017)\end{array}$ \\
\hline & ESCC & $\begin{array}{l}322 \\
\text { patients }\end{array}$ & Up-regulated & Positively associated with TNM stage; prognostic factor of OS and RFS & Jang et al. (2017) \\
\hline & ESCC & $\begin{array}{l}107 \\
\text { patients }\end{array}$ & Up-regulated & $\begin{array}{l}\text { Positively associated with lymph node metastasis and TNM stage; Prognostic factor } \\
\text { of OS }\end{array}$ & Bai et al. (2021) \\
\hline & ESCC & $\begin{array}{l}125 \\
\text { patients }\end{array}$ & Up-regulated & $\begin{array}{l}\text { Positively associated with low differentiation, lymph node metastasis, TNM stage and } \\
\text { AJCC stage; Prognostic factor of OS (AUC }=0.716) \text { and CSS }(A \cup C=0.764)\end{array}$ & $\begin{array}{l}\text { Yu and Ren, } \\
(2021)\end{array}$ \\
\hline & NSCLC & $\begin{array}{l}147 \\
\text { patients }\end{array}$ & Up-regulated & $A \cup C=0.793$ & Wang et al. (2020) \\
\hline & NSCLC & 84 patients & Up-regulated & $\begin{array}{l}\text { Positively associated with lymph node metastasis and TNM stage; AUC }=0.906 \text {, } \\
\text { sensitivity }=0.86, \text { specificity }=0.833\end{array}$ & Le and Le, (2021) \\
\hline & LC & 78 patients & Up-regulated & $\begin{array}{l}\text { Positively associated with lymph node metastasis and TNM stage; Prognostic factor } \\
\text { of OS }\end{array}$ & Guo et al. (2020) \\
\hline & ccRCC & $\begin{array}{l}480 \\
\text { patients }\end{array}$ & Up-regulated & Prognostic factor of OS & Qin et al. (2019) \\
\hline & ccRCC & $\begin{array}{l}512 \\
\text { patients }\end{array}$ & Up-regulated & Prognostic factor of OS & Zhan et al. (2021) \\
\hline & Glioma & 99 patients & Up-regulated & Prognostic factor of OS & $\begin{array}{l}\text { Zhang Y. et al. } \\
(2020)\end{array}$ \\
\hline \multicolumn{6}{|c|}{ miR-1269b } \\
\hline & $\mathrm{HCC}$ & - & Up-regulated & Prognostic factor of OS & Ma et al. (2020) \\
\hline & NSCLC & 32 patients & Up-regulated & Prognostic factor of OS & Yang et al. (2020) \\
\hline
\end{tabular}

HCC, hepatocellular carcinoma; ESCC, esophageal squamous cell carcinomas; NSCLC, Non-small cell lung cancer; LC, lung cancer; ccRCC, clear cell renal cell carcinoma; OS, overall survival; DFS, Disease-free survival; TNM, Tumour-node-metastasis; AUC, area under the curve; RFS, Recurrence-free survival; AJCC, american joint committee on cancer; CSS, Cancerspecific survival. 
miR-1269b. Therefore, the current few studies of miR-1269b may be related to relatively few detection methods.

\section{THE DIAGNOSTIC AND PROGNOSTIC VALUE OF MIR-1269}

As shown in Table 2, the high expression of miR-1269a is closely related to the clinicopathological characteristics of cancer patients. In hepatocellular carcinoma, high expression of miR1269 a is significantly positively correlated with vascular invasion and TNM staging (Gan et al., 2015). In lung cancer, highly expressed miR-1269a is significantly associated with lymph node metastasis and advanced TNM staging (Guo et al., 2020; Wang et al., 2020; Le and Le, 2021). In addition, in esophageal squamous cell carcinoma, highly expressed miR-1269a is significantly associated with poor tumor differentiation, lymph node metastasis, and TNM staging (Jang et al., 2017; Bai et al., 2021; Yu and Ren, 2021).

ROC analysis showed that the AUC of miR-1269a expression was 0.640 , indicating that the level of miR-1269a has a certain diagnostic value for hepatocellular carcinoma (Gan et al., 2015). In addition, the sensitivity, specificity, and AUC for miR-1269a were $0.598,0.786$, and 0.691 in the classification between liver fibrosis patients and hepatocellular carcinoma patients, indicating that miR-1269a can be used as a biomarker to track the progression of liver fibrosis to hepatocellular carcinoma (Elemeery et al., 2017). ROC curve analysis showed that the sensitivity, specificity, and AUC for miR-1269a in the diagnosis of lung cancer were $0.833,0.86$, and 0.906 (Le and Le, 2021). In addition, miR-1269a in serum exosomes might be used to diagnose tumors. The current study showed that serum exosomal miR-1269a can be used as a diagnostic marker for hepatocellular carcinoma (Cho et al., 2020) and non-small cell lung cancer (Wang et al., 2020).

The expression levels of miR-1269a and miR-1269b are significantly related to the prognosis of cancer patients (Table 2). The high expression of miR-1269a is significantly associated with the lower overall survival (OS) of 6 kinds of cancer patients, including hepatocellular carcinoma (Cho et al., 2020), esophageal squamous cell carcinoma (Jang et al., 2017; Bai et al., 2021; Yu and Ren, 2021), lung cancer (Guo et al., 2020), clear cell renal cell carcinoma (Qin et al., 2019; Zhan et al., 2021), glioma (Zhang Y. et al., 2020) and acute myeloid leukemia (Li and $\mathrm{Ge}, 2021)$. In hepatocellular carcinoma, high expression of miR1269 a is significantly associated with shorter disease-free survival (DFS) in patients with hepatocellular carcinoma (Cho et al., 2020) and lower cancer-specific survival (CSS) in patients with esophageal squamous cell carcinoma (Yu and Ren, 2021). These results suggest that miR-1269a is expected to be a biomarker for predicting poor prognosis in cancer patients. Similarly, high expression of miR-1269b was significantly associated with lower overall survival in patients with hepatocellular carcinoma (Ma et al., 2020) and non-small cell lung cancer (Yang et al., 2020). Highly expressed miR-1269b is also associated with cisplatin resistance in patients with nonsmall cell lung cancer (Yang et al., 2020).

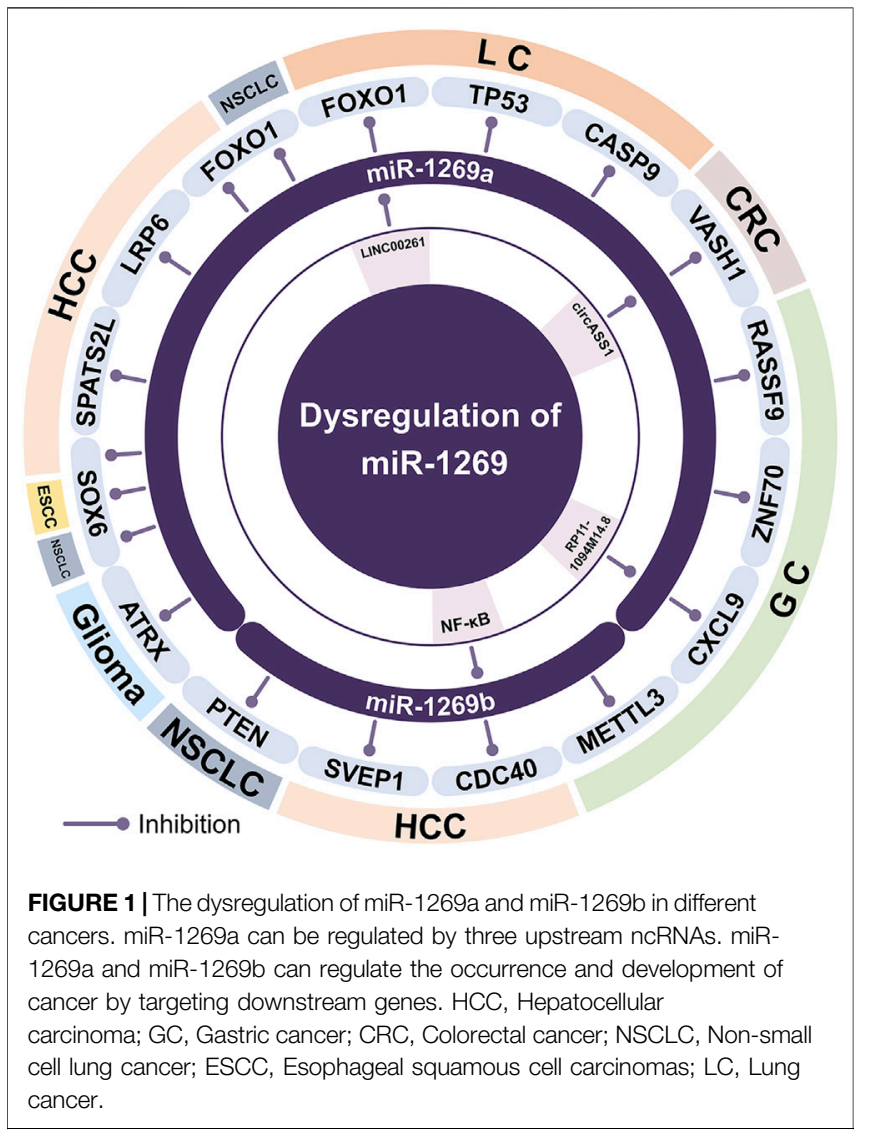

\section{MOLECULAR MECHANISM OF MIR-1269A IN TUMOR}

\section{miR-1269a and its ceRNA Network}

Competitive endogenous RNA (ceRNA) can link the function of protein-coding mRNA with the function of non-coding RNA (such as microRNA, long non-coding RNA, and circular RNA) (Qi et al., 2015). The ceRNAs of miR-1269a includes lncRNA RP11-1094M14.8, LINC00261, and circASS1, which can form the RP11-1094M14.8/miR-1269a/CXCL9 axis, LINC00261/miR1269a/FOXO1 axis and circASS1/miR-1269a/VASH1 axis.

CXCL9 plays an important regulatory role in immune infiltration, and its expression level is significantly positively correlated with the infiltration of various immune cells such as NK cells, B cells, and dendritic cells (DCs) (Zhang K. et al., 2020). There is a lncRNA RP11-1094M14.8/miR-1269a/CXCL9 axis in gastric cancer. In gastric cancer specimens of immunotherapy patients, IncRNA RP11-1094M14.8 up-regulated the expression of CXCL9 by inhibiting miR-1269a, thereby promoting CXCL9mediated lymphocyte infiltration into the lesion and inhibiting tumor growth (Zhang K. et al., 2020) (Figure 1).

FOXO1 is a key regulatory factor in the development of multiple organs or tissue cells. The absence of FOXO1 is more likely to promote the occurrence and development of tumors (Guo et al., 2020). The expression of LINC00261 is down-regulated in lung cancer, and the overexpression of LINC00261 inhibits the growth 


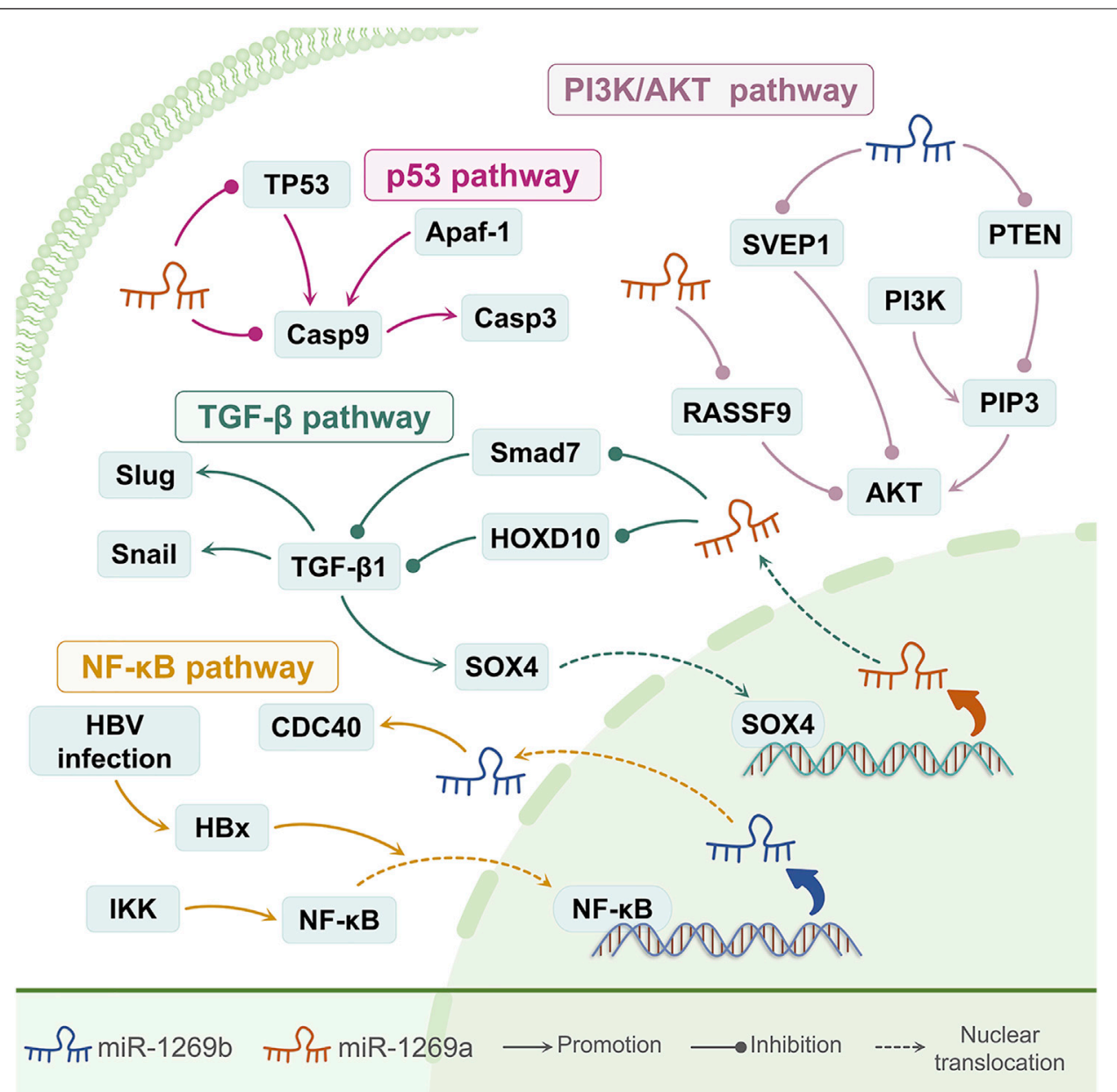

FIGURE 2 | The signaling pathways involved with miR-1269a and miR-1269b. A schematic illustration of the roles of miR-1269a and miR-1269b in multiple signaling pathways. miR-1269a can inhibit apoptosis by inhibiting TP53, the core of the p53 signaling pathway, and Casp9, the initiation factor of apoptosis. miR-1269a up-regulates TGF- $\beta$ signaling by suppressing its antagonists Smad7 and HOXD10. TGF- $\beta$, in turn, up-regulates miR-1269a via SOX4 to form a positive feedback loop in the TGF- $\beta$ signaling pathway. miR-1269a also activates the PI3K/AKT signaling pathway by inhibiting RASSF9. miR-1269b participates in the activation of the PI3K/AKT signaling pathway by inhibiting SVEP1 and PTEN, and HBx promotes tumor progression by inducing miR-1269b to up-regulate CDC40 in an NF- $\mathrm{B}$ dependent manner.

and metastasis of lung cancer by regulating the miR-1269a/FOXO1 axis (Guo et al., 2020) (Figure 1).

VASH1 is an endogenous angiogenesis inhibitor induced by VEGF and FGF-2 (Sato, 2013). VASH1 overexpression promotes cancer cell apoptosis and senescence and inhibits tumor occurrence and metastasis (Xiong et al., 2021). In colon cancer cells, the expression of circASS1 and VASH1 is reduced, and the high expression of circASS1 can down-regulate miR-1269a, thereby up-regulating VASH1 to inhibit the growth and metastasis of colon cancer (Xiong et al., 2021) (Figure 1).

\section{Downstream Genes of miR-1269a and Their Functions}

miR-1269a can directly target SOX6, FOXO1, and ATRX to affect the occurrence and development of tumors (Figure 1). SOX6 is a member of the SOX transcription factor family, which is low expressed in a variety of tumors (Jin et al., 2018). SOX6 reduces tumor cell proliferation by promoting the expression of P21 and inhibiting CyClin D1 (Jin et al., 2018). In non-small cell lung cancer, miR-1269a can down-regulate SOX6 to promote tumor growth (Jin et al., 2018). In addition, in hepatocyte carcinoma (Xiong et al., 2015) and esophageal squamous cell carcinoma (Bai et al., 2021), the miR1269a/SOX6 axis promotes cell proliferation, migration, and invasion, thereby promoting the development of tumors. FOXO1 is a transcriptional activation factor, which can regulate the expression of cell cycle blocking, apoptosis, DNA repair, and hypoxia reaction (Yang et al., 2014). In non-small cell lung cancer, miR-1269a can inhibit FOXO1 to promote cell proliferation, migration, and invasion (Wang et al., 2020). In hepatocellular carcinoma, miR-1269a/FOXO1 can up-regulate Cyclin D1, thereby promoting tumor cell proliferation (Yang et al., 2014). ATRX plays a vital role in chromatin remodeling and maintaining genome and telomere stability. It is one of the 
key molecular biomarkers for the classification and diagnosis of glioma (Zhang Y. et al., 2020). In glioma cells, the significantly increased expression of miR-1269a can promote the proliferation and invasion of glioma cells and inhibit apoptosis. miR-1269a can significantly down-regulate the expression of ATRX in vivo and in vitro, and the overexpression of ATRX can also reverse the tumorpromoting effect induced by miR-1269a (Zhang Y. et al., 2020).

\section{The Positive Feedback Regulation Between miR-1269a and TGF- $\beta$}

Transforming growth factor- $\beta$ (TGF- $\beta$ ) family members play a vital role in cellular processes such as immunosuppression, growth inhibition, EMT, and cell invasion (Xie et al., 2018). In the late stages of cancer progression, the TGF- $\beta$ signaling pathway can increase the expression of mesenchymal markers and reduce the expression of epithelial markers to promote EMT (Xie et al., 2018). In colorectal cancer, TGF- $\beta$ can activate miR-1269a by promoting Sox4, inhibit SMAD7 and HOXD10, thereby enhancing TGF- $\beta$ signaling and forming a positive feedback loop, promoting the EMT and metastasis of tumor cells (Bu et al., 2015) (Figure 2).

\section{miR-1269a and the p53 Signaling Pathway}

p53 is an important tumor suppressor gene, and abnormalities of the p53 signaling pathway usually occur in tumors with higher malignancy (Bao et al., 2018). Caspase-9 is the initiation factor of cell apoptosis, and p53 can activate the caspase-9-mediated apoptotic pathway (Kim et al., 2015). In lung cancer, miR-1269a promotes lung cancer cell proliferation and inhibits apoptosis through targeted inhibition of p53 and caspase-9 (Bao et al., 2018) (Figure 1).

\section{miR-1269a and the PI3K/AKT Signaling Pathway}

The PI3K/AKT signaling pathway can regulate the cell cycle by directly phosphorylating target proteins or indirectly controlling protein expression (Liu et al., 2019). As an N-terminal gene of the RASSF family, RASSF9 is involved in cell growth, survival, and apoptosis. By down-regulating the expression of $p$-AKT and other related proteins, RASSF9 can restrict the AKT signaling pathway (Liu et al., 2019). In gastric cancer, the overexpression of miR-1269a can inhibit RASSF9 to activate the AKT signaling pathway, and upregulate the transcription factors $\mathrm{CDK} 2$ and Cyclin D1, thereby inducing the transition of the cell cycle from the G1 phase to the S phase, promoting cell proliferation. The regulation of the PI3K/AKT signaling pathway by miR-1269a can maintain the balance between the pro-apoptotic factor Bax and the anti-apoptotic factor Bcl-2, and prevent tumor cell apoptosis (Liu et al., 2019) (Figure 1).

\section{THE MOLECULAR MECHANISMS OF MIR-1269B IN TUMORS Downstream Genes of miR-1269a and Their Functions}

m6A is a ubiquitous mRNA epigenetic modification in eukaryotes. METTL3 contains two domains that bind to S-adenosylmethionine
(SAM) and has the activity of independently catalyzing the modification of RNA m6A. METTL3 is an important regulator of malignant tumors, which can promote the malignant biological behavior of tumor cells (Kang et al., 2021). miR-1269b is low expressed in gastric cancer, while overexpression of miR-1269b can inhibit the proliferation, migration, and invasion of tumors by targeting METTL3 (Kang et al., 2021) (Figure 1).

\section{The HBx/NF-kB/miR-1269b/CDC40 Axis}

$\mathrm{HBx}$ is the smallest protein $(17 \mathrm{kDa})$ encoded by the hepatitis $\mathrm{B}$ virus (HBV). HBx does not bind to DNA but can directly inhibit or activate transcription factors to regulate downstream genes (Kong et al., 2016). HBx can activate the transcription factor NF- $\kappa B$ (Yang et al., 2020). CDC40 is a splicing factor involved in cell cycle control, which can remove E-cadherin and enhance vimentin, thereby promoting tumor cell migration (Kong et al., 2016). In hepatocellular carcinoma, $\mathrm{HBx}$ protein can promote the introduction of NF- $\kappa \mathrm{B}$ from the cytoplasm into the nucleus, thereby activating miR-1269b, up-regulating $\mathrm{CDC} 40$, and promoting the growth and migration of liver cancer cells (Kong et al., 2016) (Figure 2).

\section{miR-1269b and the PI3K/AKT Signaling Pathway}

SVEP1 is one of the most important cell adhesion molecules, and it is often highly expressed in normal tissues. In liver cancer cells, down-regulation of SVEP1 expression can significantly enhance the Akt phosphorylation at Thr308, thereby promoting the proliferation and metastasis of liver cancer cells (Chen et al., 2020). miR-1269b can activate the PI3K/Akt signaling pathway by inhibiting SVEP1 in liver cancer cells, thereby promoting tumor recurrence and metastasis (Chen et al., 2020). PTEN is a known prognostic marker and tumor suppressor for non-small cell lung cancer. Its inactivation can enhance the PI3K/AKT signaling pathway, thereby promoting the development of cisplatin resistance (Yang et al., 2020) (Figure 1). miR-1269b can inhibit the PTEN/PI3K/AKT signaling pathway, thereby driving cisplatin resistance in non-small cell lung cancer.

\section{THE MECHANISM OF MIR-1269 VARIANTS IN TUMOR}

rs73239138 is a single nucleotide polymorphism located in the sequence of miR-1269a. miR-1269a rs73239138 is also associated with a reduced risk of breast cancer among women in southeastern Iran (Sarabandi et al., 2021). In gastric cancer and liver cancer cells, overexpressed miR-1269a can inhibit the apoptosis of gastric cancer cells. In contrast, the miR-1269a variant (rs73239138) can promote the apoptosis of gastric cancer cells by up-regulating the apoptotic proteins Bik, Bim, and Bak, thereby inhibiting the tumor-promoting effect of wild-type miR-1269a (Li et al., 2017). In addition, miR-1269a can inhibit the expression of tumor suppressor gene ZNF70, while miR-1269a rs73239138 can up-regulate ZNF70, thereby reducing the susceptibility to gastric cancer (Li et al., 2017). In liver cancer, miR1269a rs73239138 can prevent miR-1269a from binding to the $3^{\prime}$ - 


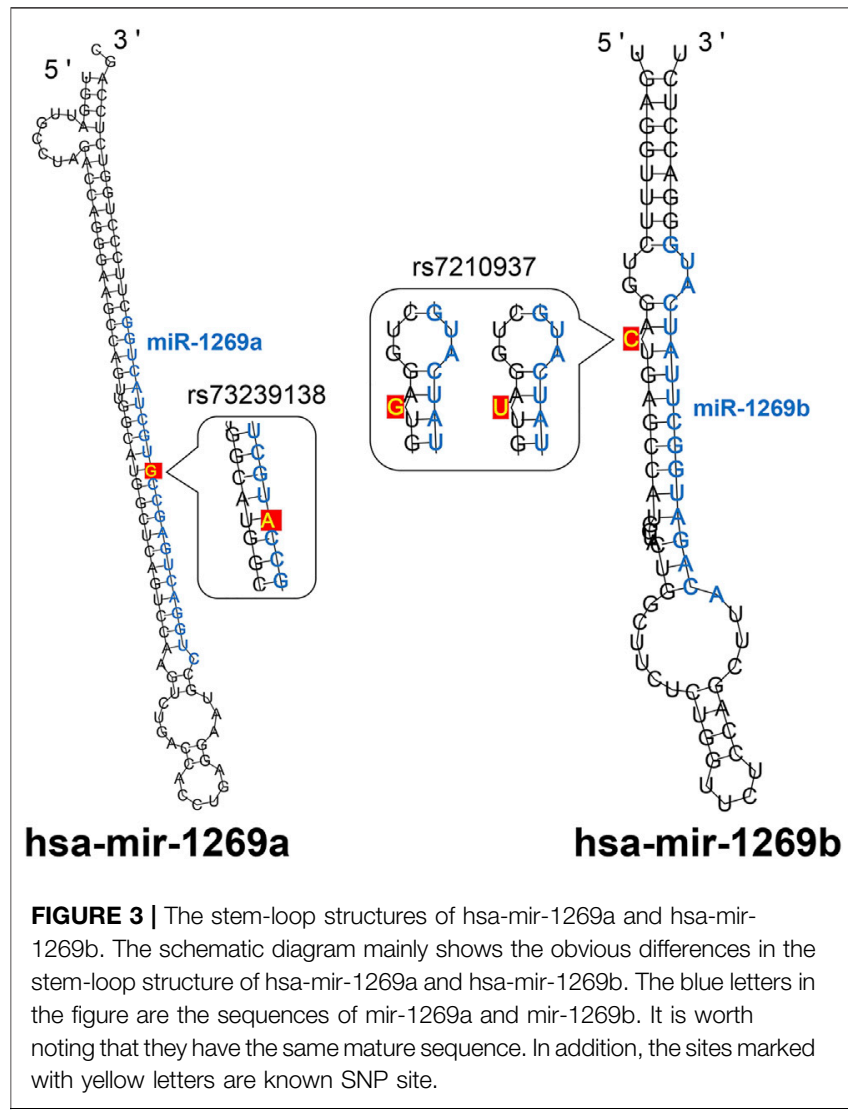

UTR of SOX6, thereby inhibiting the development of cancer (Xiong et al., 2015). At the same time, miR-1269a rs73239138 can disrupt the regulation of miR-1269a in the expression of NME1, SHMT1, SLC29A1, TP53, and UCK1, resulting in a poor prognosis for patients with advanced colon cancer receiving capecitabine chemotherapy (Mao et al., 2017).

However, another study of hepatocellular carcinoma showed that miR-1269a rs73239138 can promote tumor progression (Min et al., 2017). SPATS2L is ubiquitously expressed in a variety of tissues (Wang et al., 2021). SPATS2L is involved in ribosome biogenesis and translational control of oxidative stress response (Zhu et al., 2008). LRP6 is a transmembrane Wnt co-receptor necessary for the $\mathrm{Wnt} / \beta$ catenin signaling pathway, and excessive activation of the $\mathrm{Wnt} / \beta$ catenin signaling pathway is thought to be a key step in tumorigenesis (Dong et al., 2019). miR-1269a can down-regulate the expression of SPATS2L and LRP6, thereby inhibiting the proliferation of liver cancer cells; while miR-1269a rs73239138 can inhibit the downregulation of SPATS2L and LRP6 by miR-1269a to promote the occurrence and development of cancer (Min et al., 2017). In the future, the role of miR-1269a rs73239138 in hepatocellular carcinoma needs further research.

There is also a common genetic variant (rs7210937) of miR1269b (Figure 3). miR-1269b rs7210937 is associated with a reduced risk of oral precancerous lesions and pharyngeal squamous cell carcinoma associated with habitual chewing of betel quid, indicating that miR-1269b rs7210937 has potential protection of cancer (Chen et al., 2016).

\section{DISCUSSION}

As miRNAs have been confirmed to be involved in the progression of cancer from the initial stage to metastasis, research on miRNAs has become popular (Alwani and BajKrzyworzeka, 2021). Numerous studies have identified miRNAs as tumor diagnostic markers and potential targets for modern cancer therapy (Alwani and Baj-Krzyworzeka, 2021). In recent years, $\mathrm{miR}-1269 \mathrm{a}$ and $\mathrm{miR}-1269 \mathrm{~b}$ are involved in a variety of cancers. miR-1269a is highly expressed in 9 cancers. Growing evidence suggests that miRNAs are frequently deregulated in cancer cells, thereby affecting tumor growth, migration, invasion, apoptosis, and drug resistance (Arghiani and Shah, 2021). miR$1269 \mathrm{a}$ is of great significance in the diagnosis of hepatocellular carcinoma and lung cancer. In addition, the abnormal expression of miR-1269a is associated with the poor prognosis of 6 cancers. miR-1269a can regulate the occurrence and development of cancer by targeting downstream genes (CXCL9, SOX6, FOXO1, ATRX, RASSF9, SMAD7, HOXD10, and VASH1). At the same time, miR-1269a can interact with RP11-1094M14.8, LINC00261, and circASS1 in gastric cancer, lung cancer, and colon cancer, respectively. In colorectal cancer, a positive feedback loop is formed between miR-1269a and TGF- $\beta$ pathway to amplify the signal of cancer metastasis, which suggests that miR-1269a is expected to become a potential therapeutic target to prevent tumor metastasis. In lung cancer and gastric cancer, miR-1269a can also promote tumor cell proliferation and cell cycle progression and inhibit tumor cell apoptosis by activating the PI3K/AKT signaling pathway and inhibiting the caspase-9-mediated apoptotic pathway, respectively.

miR-1269b is highly expressed in three types of cancer, and lowly expressed in one type of cancer. miRNA is a key regulator involved in cell carcinoma proliferation, apoptosis, invasion, metastasis, EMT, angiogenesis, drug resistance, and autophagy (Xu et al., 2018). In addition, research has shown that miRNA (such as miR-21) has an important role in promoting cell proliferation and invasion, angiogenesis, and chemical and radioresistance in non-small cell lung cancer (Cecilia et al., 2018). Our work shows that the high expression of miR-1269b is associated with the lower overall survival of patients with hepatocellular carcinoma (Ma et al., 2020) and non-small cell lung cancer (Yang et al., 2020). In non-small cell lung cancer, the high expression of miR-1269b can also promote the occurrence of cisplatin resistance (Yang et al., 2020). Accordingly, miR-1269b can affect the progression of cancer by targeting downstream genes (METTL3, CDC40, SVEP1, and PTEN). In addition, miR$1269 \mathrm{~b}$ can also affect the progress of cancer through a series of regulatory methods, such as directly targeting the downstream gene METTL3 or by targeting SVEP1 and PTEN to drive the $\mathrm{PI} 3 \mathrm{~K} / \mathrm{AKT}$ signaling pathway, thereby mediating tumor recurrence and metastasis. miR-1269b can also be induced by $\mathrm{HBx}$ to up-regulate CDC40 in an NF- $\mathrm{BB}$-dependent manner to promote tumor cell growth and migration.

In hepatocellular carcinoma and gastric cancer, miR-1269a variant can reduce tumor susceptibility and inhibit tumor progression by inhibiting the effect of miR-1269a, which 


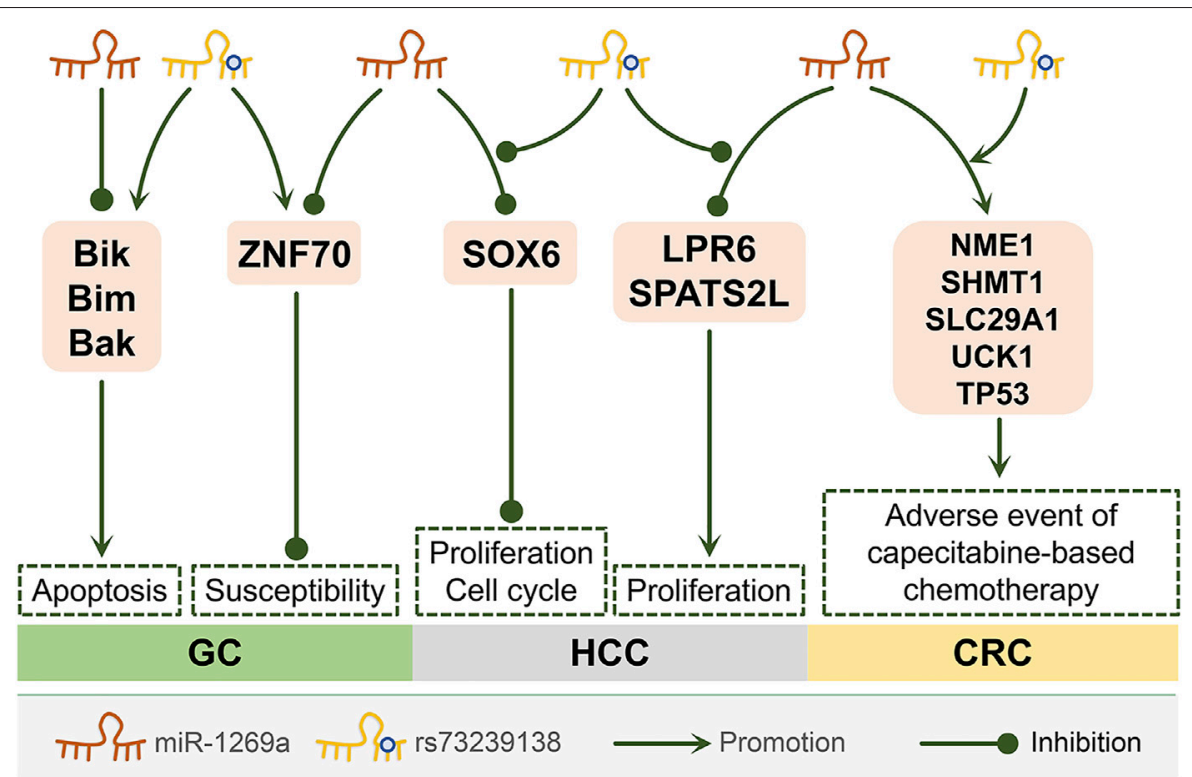

FIGURE 4 | The molecular mechanism of miR-1269a rs73239138 in different cancers. miR-1269a rs73239138 can affect three cancers through five molecular mechanisms. GC, Gastric cancer; HCC, Hepatocellular carcinoma; CRC, Colorectal cancer. (Li et al., 2017; Xiong et al., 2015; Mao et al., 2017; Min et al., 2017; Wang et al., 2021; Zhu et al., 2008; Dong et al., 2019).

provides new ideas for future targeted cancer treatments. In oral cancer, the miR-1269b variant has also been proven to have potential cancer protection.

At present, most of the researches use PCR-based technology, microarray, or next-generation sequencing technology to identify $\mathrm{miR}-1269 \mathrm{a} / \mathrm{b}$. The primer sequences they used to detect miR$1269 \mathrm{a} / \mathrm{b}$ are shown in Supplementary Table. They differentiated the roles of the miR-1269a and miR-1269b by detecting hsa-mir1269a and hsa-mir-1269b. Our work shows different molecular mechanisms between miR-1269a and miR-1269b, which may be caused by the different focus of the research content. We also checked the research of miR-1269 in the NCBI GEO database and found that hsa-mir-1269a can be detected by Illumina HumanHT-12 V4.0 expression beadchip (GPL10558), however, there is no probeset to detect hsa-mir-1269b. We believe that the current paucity of miR-1269b research may be related to the lack of detection methods for hsa-mir-1269b. Therefore, more methods need to be explored in the future for the effective detection of hsa-mir-1269b to distinguish whether there is a functional difference between miR-1269a and miR$1269 \mathrm{~b}$.

At present, our understanding of miR-1269a and miR-1269b is still very limited, and we have not conducted a comprehensive exploration of these two oncogenic miRNAs in cancer. Studies on miR-1269a or miR-1269b are often combined with other miRNAs, and there are relatively few independent studies on miR-1269a or miR-1269b. There is still some controversy as to whether the miR-1269a variant promotes or suppresses cancer. In addition, miR-1269b has been confirmed to be highly expressed in hepatocellular carcinoma, lung cancer, and oral and pharyngeal squamous cell carcinoma. However, miR-1269b is low expressed in gastric cancer, which may be caused by some unknown regulatory mechanisms in gastric cancer, and this needs to be further studied.

In summary, miR-1269a and miR-1269b are both promising miRNAs. In the future, it is necessary to further explore the mechanism of miR-1269a and miR-1269b in a variety of cancers, to establish a richer miR-1269a and miR-1269b regulatory network. At the same time, the variants of miR-1269a and miR-1269b also have great research value, which can provide support for cancer diagnosis, targeted therapy, and prognosis prediction.

\section{AUTHOR CONTRIBUTIONS}

$\mathrm{ZX}, \mathrm{CZ}$, and SD contributed to the conception, design and final approval of the submitted version. ZX and CZ collected and analyzed literature. ZX, CZ, and SD contributed to manuscript writing. All the authors conceived and gave the approval of the final manuscript.

\section{FUNDING}

The research was supported by Qiantang Scholar Fund in Zhejiang University City College.

\section{SUPPLEMENTARY MATERIAL}

The Supplementary Material for this article can be found online at: https://www.frontiersin.org/articles/10.3389/fcell.2022.809132/ full\#supplementary-material

Supplementary Table S1 | The detection of miR-1269a/b in different studies. 


\section{REFERENCES}

Alwani, A., and Baj-Krzyworzeka, M. (2021). mikroRNA Jako Cel Terapeutyczny W Chorobach Nowotworowych. Postepy Biochem. 67, 259-267. Print 2021 Sep 30. doi:10.18388/pb.2021_390

Ambros, V. (2004). The Functions of Animal microRNAs. Nature 431, 350-355. doi:10.1038/nature02871

Arghiani, N., and Shah, K. (2021). Modulating microRNAs in Cancer: NextGeneration Therapies. Cancer Biol. Med. 18, 2095-3941. doi:10.20892/j.issn. 2095-3941.2021.0294

Bai, X., Wang, Q., Rui, X., Li, X., and Wang, X. (2021). Upregulation of miR-1269 Contributes to the Progression of Esophageal Squamous Cell Cancer Cells and Is Associated with Poor Prognosis. Technol. Cancer Res. Treat. 20, 153303382098585. doi:10.1177/1533033820985858

Bao, M., Song, Y., Xia, J., Li, P., Liu, Q., and Wan, Z. (2018). miR-1269 Promotes Cell Survival and Proliferation by Targeting Tp53 and Caspase-9 in Lung Cancer. Ott Vol. 11, 1721-1732. doi:10.2147/OTT.S157715

Bu, P., Wang, L., Chen, K.-Y., Rakhilin, N., Sun, J., Closa, A., et al. (2015). miR-1269 Promotes Metastasis and Forms a Positive Feedback Loop with TGF- $\beta$. Nat. Commun. 6, 6879. doi:10.1038/ncomms7879

Cecilia, B. P., Roxana, C. P., Magdo, L., Raduly, L., Gulei, D., and BerindanNeagoe, I. (2018). Overview upon miR-21 in Lung Cancer: Focus on NSCLC. Cell. Mol. Life Sci. 75, 3539-3551. doi:10.1007/S00018-018-2877-x

Chen, H.-C., Tseng, Y.-K., Chi, C.-C., Chen, Y.-H., Yang, C.-M., Huang, S.-J., et al. (2016). Genetic Variants in microRNA-146a (C > G) and microRNA-1269b (G $>$ C) Are Associated with the Decreased Risk of Oral Premalignant Lesions, Oral Cancer, and Pharyngeal Cancer. Arch. Oral Biol. 72, 21-32. doi:10.1016/j. archoralbio.2016.08.010

Chen, L., Liu, D., Yi, X., Qi, L., Tian, X., Sun, B., et al. (2020). The Novel miR1269b-Regulated Protein SVEP1 Induces Hepatocellular Carcinoma Proliferation and Metastasis Likely through the PI3K/Akt Pathway. Cell Death Dis 11, 320. doi:10.1038/s41419-020-2535-8

Chen, Y., and Wang, X. (2020). miRDB: an Online Database for Prediction of Functional microRNA Targets. Nucleic Acids Res. 48, D127-D131. doi:10.1093/ nar/gkz757

Cho, H. J., Baek, G. O., Seo, C. W., Ahn, H. R., Sung, S., Son, J. A., et al. (2020). Exosomal microRNA-4661-5p-Based Serum Panel as a Potential Diagnostic Biomarker for Early-stage Hepatocellular Carcinoma. Cancer Med. 9, 5459-5472. doi:10.1002/cam4.3230

Dong, Y., Zhang, Y., Kang, W., Wang, G., Chen, H., Higashimori, A., et al. (2019). VSTM2A Suppresses Colorectal Cancer and Antagonizes Wnt Signaling Receptor LRP6. Theranostics 9, 6517-6531. doi:10.7150/thno. 34989

Du, Y., Yuan, S., Zhuang, X., Zhang, Q., and Qiao, T. (2021). Multiomics Differences in Lung Squamous Cell Carcinoma Patients with High Radiosensitivity Index Compared with Those with Low Radiosensitivity Index. Dis. Markers 2021, 1-11. doi:10.1155/2021/3766659

Elemeery, M. N., Badr, A. N., Mohamed, M. A., and Ghareeb, D. A. (2017). Validation of a Serum microRNA Panel as Biomarkers for Early Diagnosis of Hepatocellular Carcinoma post-hepatitis C Infection in Egyptian Patients. Wjg 23, 3864-3875. doi:10.3748/wjg.v23.i21.3864

Gan, T. Q., Tang, R. X., He, R. Q., Dang, Y. W., Xie, Y., and Chen, G. (2015). Upregulated MiR-1269 in Hepatocellular Carcinoma and its Clinical Significance. Int. J. Clin. Exp. Med. 8, 714-721.

Guo, C., Shi, H., Shang, Y., Zhang, Y., Cui, J., and Yu, H. (2020). LncRNA LINC00261 Overexpression Suppresses the Growth and Metastasis of Lung Cancer via Regulating miR-1269a/FOXO1 axis. Cancer Cel Int 20, 275. doi:10. 1186/s12935-020-01332-6

Jang, H.-J., Lee, H.-S., Burt, B. M., Lee, G. K., Yoon, K.-A., Park, Y.-Y., et al. (2017). Integrated Genomic Analysis of Recurrence-Associated Small Non-coding RNAs in Oesophageal Cancer. Gut 66, 215-225. doi:10.1136/gutjnl-2015311238

Jin, R. H., Yu, D. J., and Zhong, M. (2018). MiR-1269a Acts as an Onco-miRNA in Non-small Cell Lung Cancer via Down-Regulating SOX6. Eur. Rev. Med. Pharmacol. Sci. 22, 4888-4897. doi:10.26355/eurrev_201808_15625

Kang, J., Huang, X., Dong, W., Zhu, X., Li, M., and Cui, N. (2021). MicroRNA1269b Inhibits Gastric Cancer Development through Regulating
Methyltransferase-like 3 (METTL3). Bioengineered 12, 1150-1160. doi:10. 1080/21655979.2021.1909951

Kim, B., Srivastava, S. K., and Kim, S.-H. (2015). Caspase-9 as a Therapeutic Target for Treating Cancer. Expert Opin. Ther. Targets 19, 113-127. doi:10.1517/ 14728222.2014.961425

Kong, X.-x., Lv, Y.-r., Shao, L.-p., Nong, X.-y., Zhang, G.-l., Zhang, Y., et al. (2016). HBx-Induced MiR-1269b in NF- $\kappa B$ Dependent Manner Upregulates Cell Division Cycle 40 Homolog (CDC40) to Promote Proliferation and Migration in Hepatoma Cells. J. Transl. Med. 14, 189. doi:10.1186/s12967016-0949-y

Le, J., and Le, X. (2021). The Clinical Application Value of miR-1269 as an Unfavorable Prognostic Indicator of Lung Cancer. Am. J. Transl. Res. 13, 3270-3277.

Li, J., and Ge, Z. (2021). High HSPA8 Expression Predicts Adverse Outcomes of Acute Myeloid Leukemia. BMC Cancer 21, 475. doi:10.1186/s12885-02108193-w

Li, W., Zhang, H., Min, P., Zhu, J., Xu, D., Jiang, W., et al. (2017). Downregulated miRNA-1269a V-ariant (R-s73239138) D-ecreases the S-usceptibility to G-astric C-ancer via T-argeting ZNF70. Oncol. Lett. 14, 6345-6354. doi:10. 3892/ol.2017.7091

Liu, W.-L., Wang, H.-x., Shi, C.-x., Shi, F.-y., Zhao, L.-y., Zhao, W., et al. (2019). MicroRNA-1269 Promotes Cell Proliferation via the AKT Signaling Pathway by Targeting RASSF9 in Human Gastric Cancer. Cancer Cel Int 19, 308. doi:10. 1186/s12935-019-1026-4

Lukasik, A., Wójcikowski, M., and Zielenkiewicz, P. (2016). Tools4miRs - One Place to Gather All the Tools for miRNA Analysis. Bioinformatics 32, 2722-2724. doi:10.1093/bioinformatics/btw189

Ma, X., Zhou, L., and Zheng, S. (2020). Transcriptome Analysis Revealed Key Prognostic Genes and microRNAs in Hepatocellular Carcinoma. PeerJ 8, e8930. doi:10.7717/peerj.8930

Mao, Y., Zou, C., Meng, F., Kong, J., Wang, W., and Hua, D. (2017). The SNPs in Pre-miRNA Are Related to the Response of Capecitabine-Based Therapy in Advanced colon Cancer Patients. Oncotarget 9, 6793-6799. doi:10.18632/ oncotarget. 23190

McGeary, S. E., Lin, K. S., Shi, C. Y., Pham, T. M., Bisaria, N., Kelley, G. M., et al (2019). The Biochemical Basis of microRNA Targeting Efficacy. Science 366, 6472. doi:10.1126/science.aav1741

Min, P., Li, W., Zeng, D., Ma, Y., Xu, D., Zheng, W., et al. (2017). A Single Nucleotide Variant in microRNA-1269a Promotes the Occurrence and Process of Hepatocellular Carcinoma by Targeting to Oncogenes SPATS2L and LRP6. Bull. du Cancer 104, 311-320. doi:10.1016/j.bulcan.2016.11.021

Nunez Lopez, Y. O., Victoria, B., Golusinski, P., Golusinski, W., and Masternak, M. M. (2018). Characteristic miRNA Expression Signature and Random forest Survival Analysis Identify Potential Cancer-Driving miRNAs in a Broad Range of Head and Neck Squamous Cell Carcinoma Subtypes. Rep. Pract. Oncol. Radiother. 23, 6-20. doi:10.1016/j.rpor.2017.10.003

Qi, X., Zhang, D.-H., Wu, N., Xiao, J.-H., Wang, X., and Ma, W. (2015). ceRNA in Cancer: Possible Functions and Clinical Implications. J. Med. Genet. 52, 710-718. doi:10.1136/jmedgenet-2015-103334

Qin, S., Shi, X., Wang, C., Jin, P., and Ma, F. (2019). Transcription Factor and miRNA Interplays Can Manifest the Survival of ccRCC Patients. Cancers 11, 1668. doi:10.3390/cancers11111668

Sarabandi, S., Sattarifard, H., Kiumarsi, M., Karami, S., Taheri, M., Hashemi, M., et al. (2021). Association between Genetic Polymorphisms of miR-1307, miR1269, miR-3117 and Breast Cancer Risk in a Sample of South East Iranian Women. Asian Pac. J. Cancer Prev. 22, 201-208. doi:10.31557/APJCP.2021.22. 1.201

Sato, Y. (2013). The Vasohibin Family: a Novel Family for Angiogenesis Regulation. J. Biochem. 153, 5-11. doi:10.1093/jb/mvs128

Scaravilli, M., Porkka, K. P., Brofeldt, A., Annala, M., Tammela, T. L., Jenster, G. W., et al. (2015). MiR-1247-5p Is Overexpressed in Castration Resistant Prostate Cancer and Targets MYCBP2. Prostate 75, 798-805. doi:10.1002/ pros. 22961

Sticht, C., De La Torre, C., Parveen, A., and Gretz, N. (2018). miRWalk: An Online Resource for Prediction of microRNA Binding Sites. PLoS One 13, e0206239. doi:10.1371/journal.pone.0206239

Wang, H., Wang, X., Xu, L., Zhang, J., and Cao, H. (2021). Analysis of the EGFR Amplification and CDKN2A Deletion Regulated Transcriptomic Signatures 
Reveals the Prognostic Significance of SPATS2L in Patients with Glioma. Front. Oncol. 11, 551160. doi:10.3389/fonc.2021.551160

Wang, X., Gao, J., Zhou, B., Xie, J., Zhou, G., and Chen, Y. (2019). Identification of Prognostic Markers for Hepatocellular Carcinoma Based on miRNA Expression Profiles. Life Sci. 232, 116596. doi:10.1016/j.lfs.2019.116596

Wang, X., Jiang, X., Li, J., Wang, J., Binang, H., Shi, S., et al. (2020). Serum Exosomal miR -1269a Serves as a Diagnostic Marker and Plays an Oncogenic Role in Non-small Cell Lung Cancer. Thorac. Cancer 11, 3436-3447. doi:10. 1111/1759-7714.13644

Wojcicka, A., Swierniak, M., Kornasiewicz, O., Gierlikowski, W., Maciag, M., Kolanowska, M., et al. (2014). Next Generation Sequencing Reveals microRNA Isoforms in Liver Cirrhosis and Hepatocellular Carcinoma. Int. J. Biochem. Cel Biol. 53, 208-217. doi:10.1016/j.biocel.2014.05.020

Xie, F., Ling, L., van Dam, H., Zhou, F., and Zhang, L. (2018). TGF- $\beta$ Signaling in Cancer Metastasis. Acta Biochim. Biophys. Sin. 50, 121-132. doi:10.1093/abbs/ gmx123

Xiong, G., Wang, Y., Ding, Q., and Yang, L. (2015). Hsa-mir-1269 Genetic Variant Contributes to Hepatocellular Carcinoma Susceptibility through Affecting SOX6. Am. J. Transl. Res. 7, 2091-2098.

Xiong, H.-L., Zhong, X.-H., Guo, X.-H., Liao, H.-J., and Yuan, X. (2021). circASS1 Overexpression Inhibits the Proliferation, Invasion and Migration of Colorectal Cancer Cells by Regulating the miR-1269a/VASH1 axis. Exp. Ther. Med. 22, 1155. doi:10.3892/etm.2021.10589

Xu, X., Tao, Y., Shan, L., Chen, R., Jiang, H., Qian, Z., et al. (2018). The Role of MicroRNAs in Hepatocellular Carcinoma. J. Cancer 9, 3557-3569. doi:10.7150/ jca. 26350

Yang, W., Xiao, W., Cai, Z., Jin, S., and Li, T. (2020). miR-1269b Drives Cisplatin Resistance of Human Non-small Cell Lung Cancer via Modulating the PTEN/ PI3K/AKT Signaling Pathway. Ott Vol. 13, 109-118. doi:10.2147/OTT.S225010

Yang, X.-W., Shen, G.-Z., Cao, L.-Q., Jiang, X.-F., Peng, H.-P., Shen, G., et al. (2014). MicroRNA-1269 Promotes Proliferation in Human Hepatocellular Carcinoma via Downregulation of FOXO1. BMC Cancer 14, 909. doi:10. 1186/1471-2407-14-909

Yu, Y., and Ren, K.-M. (2021). Development of a Prognostic Prediction Model Based on microRNA-1269a in Esophageal Cancer. Wjgo 13, 943-958. doi:10. 4251/wjgo.v13.i8.943
Zhan, Y., Zhang, R., Li, C., Xu, X., Zhu, K., Yang, Z., et al. (2021). A microRNAclinical Prognosis Model to Predict the Overall Survival for Kidney Renal clear Cell Carcinoma. Cancer Med. 10, 6128-6139. doi:10.1002/cam4.4148

Zhang, K., Zhang, L., Mi, Y., Tang, Y., Ren, F., Liu, B., et al. (2020). A ceRNA Network and a Potential Regulatory axis in Gastric Cancer with Different Degrees of Immune Cell Infiltration. Cancer Sci. 111, 4041-4050. doi:10.1111/ cas. 14634

Zhang, S., Sun, Q., Jiang, X., and Gao, F. (2018). Clinical Significance of Expression of Hsa-Mir-1247 and Hsa-Mir-1269a in Ectopic Pregnancy Due to Salpingitis. Exp. Ther. Med. 15, 4901-4905. doi:10.3892/etm.2018.5998

Zhang, Y., Wang, Q., Luo, N., Liu, J., Ren, H., Shao, X., et al. (2020). MicroRNA-1269a Promotes Proliferation and Arrest of Apoptosis of Glioma Cells by Directly Targeting ATRX. Front. Oncol. 10, 563901. doi:10.3389/fonc.2020.563901

Zhao, Y., Xu, L., Wang, X., Niu, S., Chen, H., and Li, C. (2021). A Novel Prognostic mRNA/miRNA Signature for Esophageal Cancer and its Immune Landscape in Cancer Progression. Mol. Oncol. 15, 1088-1109. doi:10.1002/1878-0261.12902

Zhu, C.-H., Kim, J., Shay, J. W., and Wright, W. E. (2008). SGNP: an Essential Stress Granule/Nucleolar Protein Potentially Involved in 5.8s rRNA Processing/ transport. PLoS. One 3, e3716. doi:10.1371/journal.pone.0003716

Conflict of Interest: The authors declare that the research was conducted in the absence of any commercial or financial relationships that could be construed as a potential conflict of interest.

Publisher's Note: All claims expressed in this article are solely those of the authors and do not necessarily represent those of their affiliated organizations, or those of the publisher, the editors and the reviewers. Any product that may be evaluated in this article, or claim that may be made by its manufacturer, is not guaranteed or endorsed by the publisher.

Copyright $\odot 2022$ Xie, Zhong and Duan. This is an open-access article distributed under the terms of the Creative Commons Attribution License (CC BY). The use, distribution or reproduction in other forums is permitted, provided the original author(s) and the copyright owner(s) are credited and that the original publication in this journal is cited, in accordance with accepted academic practice. No use, distribution or reproduction is permitted which does not comply with these terms. 